Archives de sciences sociales des religions

176 | octobre-décembre 2016

Bulletin Bibliographique

\title{
Michel Mallèvre, Les évangéliques. Un nouveau visage du christianisme?
}

Paris-Namur, Éditions jésuites, coll. « Que penser de... ? », 2015, 117 p.

Rodolfo de Roux

\section{OpenEdition}

\section{Journals}

Édition électronique

URL : http://journals.openedition.org/assr/28299

DOI : $10.4000 /$ assr.28299

ISSN : $1777-5825$

\section{Éditeur}

Éditions de l'EHESS

Édition imprimée

Date de publication : 31 décembre 2016

Pagination : 354

ISSN : 0335-5985

Référence électronique

Rodolfo de Roux, « Michel Mallèvre, Les évangéliques. Un nouveau visage du christianisme? ", Archives de sciences sociales des religions [En ligne], 176 | octobre-décembre 2016, mis en ligne le 17 juillet

2017, consulté le 24 septembre 2020. URL : http://journals.openedition.org/assr/28299; DOI : https:// doi.org/10.4000/assr.28299

Ce document a été généré automatiquement le 24 septembre 2020.

(C) Archives de sciences sociales des religions 


\section{Michel Mallèvre, Les évangéliques. Un nouveau visage du christianisme?}

Paris-Namur, Éditions jésuites, coll. «Que penser de... ?», 2015, 117 p.

Rodolfo de Roux

\section{RÉFÉRENCE}

Michel Mallèvre, Les évangéliques. Un nouveau visage du christianisme ?, Paris-Namur, Éditions jésuites, coll. «Que penser de... ?», 2015, 117 p.

1 Cet ouvrage, destiné à un large public, constitue une introduction brève, mais claire et bien informée, à un phénomène fort complexe qui représente désormais une part très importante du christianisme. D'emblée, l'auteur brosse le tableau de l'histoire du protestantisme évangélique (chap. 1) en soulignant qu'il est composé de deux courants. D'une part, un courant «orthodoxe piétiste» attaché aux fondamentaux du protestantisme et marqué par une forte piété personnelle (prière, lecture de la Bible), qui regroupe diverses traditions apparues depuis le $\mathrm{xVI}^{\mathrm{e}}$ siècle (mennonites, anabaptistes, baptistes, méthodistes...), et qu'on pourrait qualifier aussi d'« évangélisme traditionnel ». D'autre part, un courant "pentecôtiste charismatique », qui a commencé à se développer au début du $\mathrm{xx}^{\mathrm{e}}$ siècle, mettant l'accent sur l'efficacité de l'action miraculeuse de Dieu par l'Esprit Saint à travers la prophétie, la glossolalie et la guérison; ce dernier courant représenterait les deux tiers du mouvement évangélique au sens large.

2 Après avoir montré comment sont apparues un certain nombre de familles confessionnelles, tant chez les évangéliques traditionnels que chez les pentecôtistes, au cours de leur histoire, l'auteur souligne l'effort actuel des évangéliques pour surmonter l'émiettement par des réconciliations et l'instauration de réseaux (chap. 2), et précise au chapitre suivant l'importance du mouvement évangélique en Europe francophone (France, Benelux, Suisse). 
3 Le chapitre 4 est destiné à mieux comprendre les convictions doctrinales fondamentales des évangéliques en tenant compte de la grande diversité à l'intérieur de chacun de ses deux courants. Toujours attentif à la complexité du phénomène, l'auteur aborde les convictions éthiques des évangéliques (chap. 5) en précisant que s'ils tiennent des positions plutôt «conservatrices» sur le plan de l'anthropologie morale (début et fin de vie) et de l'éthique personnelle (mariage, homosexualité), il serait pourtant faux de dire qu'ils sont tous indifférents à l'engagement dans la société.

Dans le chapitre 6, l'auteur s'interroge sur les causes sociologiques de l'essor des pentecôtistes, sans négliger les dérives qui les affectent, et réfléchit au défi que cela représente pour les formes plus traditionnelles de vie chrétienne, en particulier le catholicisme. Michel Mallèvre, père dominicain, est directeur de l'Institut supérieur d'études œcuméniques (Paris) et président de l'Association francophone œcuménique de missiologie, il n'y a donc rien d'étonnant à ce que cet acteur et observateur éclairé des dialogues entre les évangéliques et l'Église catholique en France finisse son ouvrage (chap. 7) en s'interrogeant de façon respectueuse et pertinente sur les difficultés et les perspectives d'un dialogue entre évangéliques et catholiques.

5 Nul doute que ce livre, qui va droit à l'essentiel et qui est animé par un vrai souci pédagogique, sera un guide utile pour les non initiés au monde des évangéliques. 